\title{
Pengaruh Suplementasi Lemak Terproteksi Terhadap Konsumsi dan Kecernaan Nutrien Sapi Perah Friesian Holstein
}

\author{
A. Pramono ${ }^{1}$, A. Yusuf ${ }^{1}$, S. D. Widyawati ${ }^{1}$, H. Hartadi ${ }^{2}$ \\ ${ }^{1}$ Program Studi Peternakan, Fakultas Pertanian, Universitas Sebelas Maret, Surakarta \\ ${ }^{2}$ Fakultas Peternakan, Universitas Gadjah Mada, Yogyakarta
}

\begin{abstract}
ABSTRAK
Penelitian ini bertujuan untuk mengetahui pengaruh suplementasi lemak terproteksi terhadap konsumsi dan kecernaan nutrien sapi perah Friesian Holstein (FH). Penelitian dilaksanakan selama 12 minggu, di Balai Besar Pembibitan Ternak Unggul Sapi Perah (BBPTU-SP) Baturraden. Materi yang digunakan adalah sapi FH sebanyak 12 ekor dengan perlakuan P0: ransum basal dan P1: ransum basal $+3 \%$ suplementasi lemak terproteksi. Setiap perlakuan dilakukan ulangan sebanyak 6 ulangan. Data yang diperoleh dianalisis menggunakan independent-samples t-test. Hasil penelitian menunjukkan bahwa suplementasi lemak terproteksi tidak memberikan pengaruh $(\mathrm{P}>0,05)$ terhadap konsumsi bahan kering $(\mathrm{KBK})$, konsumsi bahan organik $(\mathrm{KBO})$, kecernaan bahan kering $(\mathrm{KcBK})$, kecernaan bahan organik $(\mathrm{KcBO})$ sapi FH.
\end{abstract}

Kata kunci : Kecernaan ransum, Sapi perah FH, Suplementasi lemak terproteksi

\section{The Effect of Protected Fat Supplement on the Nutrient Consumption and Digestibility of Friesian Holstein Dairy Cow}

\begin{abstract}
The research aims to evaluate protected fat supplementation to Friesian Holstein (FH) dairy cattle based on diet digestibility (dry matter and organic matter consumption; dry matter and organic matter digestibility). The reseach was conducted for 12 weeks, at the Breeding Center for Dairy Cattle (BBPTU-SP) Baturraden. The material used is 12 FH dairy cows. The experiment consists of two treatment i.e.P0: basal diet and P1: basal diet $+3 \%$ protected fat supplementation. Each treatment wasrepeated 6 times.Data were analyzed by independent samples t-test analysis. Result showed that fat protected supplementation had no effect on dry matter and organic matter consumption; dry matter and organic matter digestibility.
\end{abstract}

Keywords: Diet digestibility, FH Dairy cattle, Fat protected supplementation

\section{PENDAHULUAN}

Ketersediaan nutrien dalam ransum sangat penting untuk mengoptimalkan produktivitas sapi perah. Nutrien dalam ransum akan dicerna dan dimetabolisme untuk memenuhi kebutuhan hidup pokok, produksi dan reproduksi (Pramono et al., 2017). Energi merupakan salah satu komponen nutrien yang harus dipenuhi pada sapi perah terutama pada trimester 1 (satu). Hal ini dikarenakan pada masa ini terjadi peningkatan produksi susu sampai puncak produksi yang menyebabkan prioritas pemanfaatan energi utamanya untuk produksi susu. Fenomena yang terjadi adalah energi dari bahan pakan yang dikonsumsi tidak mencukupi kebutuhan sehingga terjadi negative energy balance (NEB) berakibat rendahnya produksi susu, persistensi dan rendahnya kinerja reproduksi post partus. Peningkatan asupan energi pada sapi perah dapat dilakukan dengan meningkatkan densitas energi pakan melalui penggunaan lemak (minyak). Salah satu sumber energi potensial yang banyak tersedia, dan harganya relatif murah adalah minyak ikan lemuru. Minyak ikan lemuru banyak mengandung

\footnotetext{
*Penulis Korespondensi: A. Pramono

Alamat : Jl. Ir. Sutami No 36 A Kentingan Jebres Surakarta

E-mail : ahmad_pram@staff.uns.ac.id
}

asam lemak tidak jenuh tinggi. Kendala yang ditemukan apabila minyak ikan lemuru diberikan secara langsung dalam pakan adalah (1) terjadinya proses hidrogenasi dalam rumen yang mengubah lemak tidak jenuh menjadi jenuh, (2) pemberian minyak dapat mengganggu aktivitas mikrobia selulolitik, sehingga menurunkan laju fermentasi serat kasar dalam rumen, (3) minyak ikan lemuru mempunyai bau (aroma) yang amis karena mengandung senyawa trimethil amin oksida yang apabila dicampurkan secara langsung dalam ransum akan menyebabkan rendahnya palatabilitas pakan (Pramono et al., 2013).

Pemberian asam lemak tidak jenuh pada sapi perah dapat meningkatkan kinerja reproduksi dikarenakan: (1) asam lemak merupakan prekursor hormon- hormon steroid, (2) asam lemak sebagai prekursor hormon prostaglandin, (3) konsumsi asam lemak tidak jenuh dapat mempengaruhi fungsi jaringan reproduksi dengan kemampuannya mengubah komposisi membran sel yang kemudian akan mengubah fluiditas (sifat cair) membran yang dapat mempengaruhi transformasi nutrien di dalam sel sehingga dapat mempengaruhi fungsi biologis jaringan organ-organ reproduksi seperti meningkatkan jumlah folikel dalam ovarium, meningkatkan ukuran folikel dominan dan kadar luteinizing hormone serta terbukti dapat 
Tabel 1. Kandungan nutrien bahan pakan penyusun ransum penelitian

\begin{tabular}{llcccccc}
\hline \hline No & \multicolumn{1}{c}{ Nama bahan } & BK (\%) & (PK\%) & LK (\%) & SK (\%) & Abu (\%) & $\begin{array}{c}\text { BETN } \\
(\%)\end{array}$ \\
\hline 1 & Rumput gajah $^{\text {a) }}$ & 12,74 & 11,51 & 10,62 & 32,97 & 10,67 & 34,28 \\
2 & Konsentrat 1 $^{\text {b) }}$ & 89,93 & 18,74 & 3,51 & 15,39 & 10,70 & 51,66 \\
3 & Konsentrat 2 $^{\text {c) }}$ & 89,57 & 22,12 & 4,19 & 13,77 & 8,00 & 51,92 \\
4 & Suplemen lemak terproteksi $^{d)}$ & 100 & 17,30 & 23,15 & 0,19 & 18,67 & 40,69 \\
\hline
\end{tabular}

Keterangan: a) Hasil analisis Laboratorium Ilmu Nutrisi dan Makanan Ternak Fakultas Peternakan Universitas Jenderal Soedirman Purwokerto

b) Hasil analisis Laboratorium Balai Pengujian Mutu Pakan Ternak KEMENTAN

c) Hasil analisis Laboratorium Balai Pengujian Mutu Pakan Ternak KEMENTAN

d) Hasil analisis Laboratorium Nutrisi dan Makanan Ternak Fakultas Pertanian Universitas Sebelas Maret Surakarta

meningkatkan fertilitas ternak (Santos et al., 2008; Zachut et al., 2010).

Proteksi asam lemak pada ternak ruminansia sangat diperlukan supaya minyak tidak mengalami hidrogenasi, tidak mengganggu aktivitas mikrobia dalam rumen dan mengeliminir bau amis. Pakan suplemen lemak terproteksi pada penelitian ini dibuat dengan metode penyabunan dan mikroenkapsulasi, sehingga pakan suplemen lemak terproteksi tidak terdegradasi sempurna di dalam rumen, namun dapat terurai dan terabsorbsi di dalam abomasum sampai dengan usus halus (Pramono et al., 2013). Penelitian ini bertujuan untuk mengevaluasi suplementasi lemak terproteksi terhadap kecernaan ransum sapi perah Friesian Holstein.

\section{MATERI DAN METODE}

\section{Materi}

Penelitian ini dilaksanakan di Balai Besar Pembibitan Ternak Unggul Sapi Perah (BBPTU-SP) Baturraden Purwokerto dan di Laboratorium Nutrisi dan Makanan Ternak Fakultas Pertanian Universitas Sebelas Maret Surakarta.

Bahan dan alat yang digunakan dalam penelitian antara lain :

1. Ternak

Ternak yang digunakan dalam penelitian ini adalah 12 ekor sapi FH umur 3-6 tahun/ jarak laktasi 2-4 dengan berat badan rata-rata $525 \pm 40,02 \mathrm{~kg}$ dengan status fisiologis post partus dan tidak bunting. 2. Kandang dan peralatan

Penelitian ini menggunakan kandang yang diisi oleh 12 ekor sapi dengan luas 2,5 x 1,5 m per ekor dan dilengkapi dengan tempat pakan dan air minum. Peralatan yang digunakan berupa timbangan. Timbangan yang digunakan terdiri dari timbangan pakan konsentrat, timbangan rumput dan timbangan untuk menimbang berat sapi perah.

\section{Ransum}

Ransum yang digunakan dalam penelitian ini yaitu terdiri dari: hijauan, konsentrat 1, konsentrat 2 dan pakan suplemen lemak terproteksi. Ransum disusun berdasarkan kebutuhan nutrien ternak sapi perah dan kandungan nutrien bahan pakan yang tersaji pada Tabel 1 dan 2 .

Bahan baku yang digunakan dalam pembuatan pakan suplemen lemak terproteksi adalah minyak ikan lemuru. Pakan suplemen ini dibuat dengan menggunakan metode penyabunan dan mikroenkapsulasi. Komposisi kimia pakan suplemen tercantum pada Tabel 1.

Pelaksanaan penelitian dibagi menjadi dua tahap yaitu tahap adaptasi dan tahap koleksi data. Tahap adaptasi dilakukan selama 2 minggu, tujuan dari periode ini untuk membiasakan ternak pada ransum dan keadaan sekitarnya sehingga akan didapatkan respons positif terhadap perlakuan yang diberikan. Tahap koleksi data dilakukan setelah masa adaptasi selama 1 minggu. Kegiatan yang dilakukan antara lain mencatat pakan yang diberikan, pakan yang dikonsumsi dan sisa pakan setiap hari serta menimbang dan mencatat berat feses. Koleksi sampel feses dilakukan dengan cara mengumpulkan feses sapi per ekor setiap hari. Feses dikumpulkan dan ditimbang per 6 jam setiap hari. Setiap penimbangan per 6 jam diambil 3\% dari berat feses untuk sampel. Sampel tersebut dikomposit untuk memperoleh sampel feses harian per ekor. Sampel feses yang akan diuji diperoleh dengan melakukan komposit sampel feses per ekor selama 7 hari. Sampel kemudian dikeringkan dengan panas matahari, kemudian diuji dengan analisis proksimat. Penimbangan feses dilakukan sebelum pemberian pakan.

4. Pemberian Pakan

Pemberian pakan sesuai dengan kebutuhan masing-masing sapi perah, dengan frekuensi pemberian sesuai dengan jadwal yang ada di BBPTUSP Baturraden yakni konsentrat yang telah dicampur

Tabel 2. Rasio bahan pakan penyusun ransum penelitian

\begin{tabular}{clcc}
\hline \multicolumn{1}{c}{ Nama Bahan } & \multicolumn{2}{c}{ Rasio (\%) } \\
\cline { 3 - 4 } & \multicolumn{1}{c}{ No. } & $\mathrm{P}_{0}$ & $\mathrm{P}_{1}$ \\
\hline 1 & Rumput gajah & 40 & 50 \\
2 & Konsentrat 1 & 10 & 37 \\
3 & Konsentrat 2 & - & 10 \\
4 & Pakan suplemen lemak terproteksi & 100 & 3 \\
\hline \multicolumn{2}{c}{ Jumlah } & & 100 \\
\hline
\end{tabular}


Tabel 3. Komposisi dan kandungan nutrien dalam ransum penelitian

\begin{tabular}{|c|c|c|c|}
\hline \multirow{2}{*}{ No. } & \multirow{2}{*}{ Komposisi Nutrien (\%) } & \multicolumn{2}{|c|}{ Kandungan Nutrien (\%) } \\
\hline & & $\mathrm{P}_{0}$ & $\mathrm{P}_{1}$ \\
\hline 1 & Bahan kering & 51,30 & 51,60 \\
\hline 2 & Protein kasar & 15,46 & 15,42 \\
\hline 3 & Lemak kasar & 7,13 & 7,73 \\
\hline 4 & Serat kasar & 24,02 & 23,56 \\
\hline 5 & $\mathrm{Abu}$ & 10,39 & 10,63 \\
\hline 6 & Bahan ekstak tanpa nitrogen & 43,00 & 42,67 \\
\hline 7 & Total digestible nutrien & 64,49 & 65,33 \\
\hline
\end{tabular}

Sumber: hasil perhitungan Tabel 1 dan Tabel 2

dengan pakan suplemen diberikan 2 kali sehari yaitu pukul 07.00 WIB dan pukul 15.00 WIB. Hijauan diberikan tiga kali sehari yaitu pukul 07.00 WIB, 12.00 WIB dan pukul 17.00 WIB sedangkan air minum disediakan secara adlibitum.

\section{Metode}

Penelitian ini dilakukan secara eksperimental dan menggunakan uji $\mathrm{t}$ dengan 2 perlakuan dan 6 ulangan masing-masing yakni:

$\mathrm{P}_{0}=$ Ransum Basal

$P_{1}=$ Ransum Basal $+3 \%$ pakan suplemen lemak terproteksi dari ransum

Peubah yang diamati dalam penelitian adalah:

a. Konsumsi Bahan Kering (kg/ekor/hari) Konsumsi BK $(\mathrm{kg})=($ Pemberian $(\mathrm{kg}) \mathrm{x} \%$ $\mathrm{BK})$ - (sisa (kg) x \% BK)

b. Konsumsi Bahan Organik (kg/ekor/hari) Konsumsi BO $(\mathrm{kg})=(\mathrm{BK}$ pemberian $\mathrm{x} \%$ $\mathrm{BO})$ - (BK sisa $\mathrm{x} \% \mathrm{BO})$

c. Kecernaan Bahan Kering (kg/ekor/hari) KecernaanBK $(\%)=\frac{(\text { KonsumsiBK }- \text { EkskresiBK })}{\text { KonsumsiBK }} \times 100 \%$

d. Kecernaan bahan organik ( $\mathrm{kg} / \mathrm{ekor} / \mathrm{hari})$

Kecernaan BO $(\%)=\frac{(\text { Konsumsi BO }- \text { Ekskresi BO })}{\text { Konsumsi BO }} \times 100 \%$

\section{Analisis Data}

Data yang diperoleh dianalisis menggunakan uji $\mathrm{t}$ tidak berpasangan/independent-samples $t$-test.

\section{HASIL DAN PEMBAHASAN}

\section{Konsumsi Bahan Kering}

Rerata konsumsi bahan kering (KBK) pada sapi perah Friesian Holstein (FH) dalam penelitian ini tercantum pada Tabel 4.

Rerata konsumsi bahan kering sebesar 17,54 dan 17,76 (kg/ekor/hari) untuk masing-masing perlakuan. Hasil analisis variansi (Anova) menunjukkan bahwa suplementasi lemak terproteksi tidak mempengaruhi konsumsi bahan kering. Hal ini menunjukkan bahwa suplementasi lemak terproteksi tidak mengakibatkan penurunan palatabilitas ransum sehingga konsumsi bahan kering antara perlakuan dengan kontrol setara. Pemberian minyak ikan lemuru secara langsung (tanpa perlakuan tertentu) pada ransum umumnya akan menurunkan palatabilitas ternak akibat bau amis yang sangat menyengat dari minyak ikan lemuru yang mengandung senyawa trimethil amin oksida (Pramono et al., 2013). Dengan adanya perlakuan proteksi terhadap minyak ikan lemuru, bau amis menjadi berkurang dan dengan berubahnya bentuk minyak menjadi tepung selain tidak menurunkan palatabilitas ransum juga memudahkan dalam handling pakan suplemen lemak terproteksi.

Utomo, (2010) menyatakan bahwa palatabilitas merupakan gabungan dari beberapa faktor yang mewakili rangsangan dari penglihatan, aroma, sentuhan dan rasa yang dipengaruhi oleh faktor fisik dan kimia dari ternak yang berbeda. Sedangkan menurut Pond et al. (1995) palatabilitas merupakan daya tarik suatu pakan atau bahan pakan untuk menimbulkan selera makan dan langsung dimakan oleh ternak. Palatabilitas ternak dipengaruhi oleh beberapa faktor diantaranya rasa, bentuk dan bau dari pakan itu sendiri (Tilman et al., 1998).

Suplementasi lemak terproteksi pada penelitian ini tidak mempengaruhi konsumsi bahan kering dapat juga disebabkan kandungan nutrien ransum terutama serat kasar ransum pada kedua perlakuan hampir sama yaitu sebesar 24,02\% (P0) dan 23,56\% (P1). Hal ini dikarenakan pakan yang voluminious (bulky) atau pakan yang mengandung serat kasar yang tinggi akan menurunkan jumlah konsumsi pakan (Kamal, 1994). Hasil penelitian ini lebih tinggi bila dibandingkan dengan penelitian Astuti et al. (2009) sapi perah yang mendapatkan substitusi 300 $\mathrm{g} /$ hari/liter susu pakan suplemen mempunyai konsumsi bahan kering 13,51 kg/ekor/hari dan

Tabel 4. Rerata konsumsi bahan kering sapi FH betina (kg/ekor/hari)

\begin{tabular}{|c|c|c|c|c|c|c|c|}
\hline \multirow{2}{*}{ Perlakuan } & \multicolumn{6}{|c|}{ Ulangan } & \multirow{2}{*}{ Rerata } \\
\hline & 1 & 2 & 3 & 4 & 5 & 6 & \\
\hline P0 & 16,77 & 15,05 & 17,20 & 18,56 & 18,35 & 19,32 & $17,54^{\mathrm{ns}}$ \\
\hline $\mathrm{P} 1$ & 16,96 & 16,51 & 17,66 & 17,53 & 19,27 & 17,76 & $17,76^{\mathrm{ns}}$ \\
\hline
\end{tabular}

NS: non significant (berbeda tidak nyata) 
Tabel 5. Rerata konsumsi bahan organik sapi Friesian Holstein (FH) (kg/ekor/hari)

\begin{tabular}{|c|c|c|c|c|c|c|c|}
\hline \multirow{2}{*}{ Perlakuan } & \multicolumn{6}{|c|}{ Ulangan } & \multirow{2}{*}{ Rerata } \\
\hline & 1 & 2 & 3 & 4 & 5 & 6 & \\
\hline P0 & 14,99 & 13,54 & 15,38 & 16,59 & 16,40 & 17,27 & $15,68^{\mathrm{ns}}$ \\
\hline P1 & 15,20 & 14,79 & 15,83 & 15,71 & 17,26 & 15,92 & $15,79^{\mathrm{ns}}$ \\
\hline
\end{tabular}

suplementasi $300 \mathrm{~g} /$ hari/liter susu pakan suplemen mempunyai konsumsi bahan kering 16,73 $\mathrm{kg} / \mathrm{ekor} / \mathrm{hari}$.

\section{Konsumsi Bahan Organik}

Rerata konsumsi bahan organik pada sapi perah Friesian Holstein $(\mathrm{FH})$ dalam penelitian ini tercantum pada Tabel 5.

Rerata konsumsi bahan organik (BO) pada masing-masing perlakuan P0 dan P1 pada penelitian ini secara berturut-turut adalah 15,68 dan 15,79 (kg/ekor/hari). Hasil anova menunjukkan bahwa pengaruh suplementasi lemak terproteksi tidak mempengaruhi konsumsi bahan organik. Hal ini dikarenakan konsumsi bahan organik mengikuti konsumsi bahan kering. Apabila konsumsi bahan kering naik maka konsumsi bahan organik akan naik pula begitu juga sebaliknya. Nutrien yang terkandung dalam bahan kering juga terkandung dalam bahan organik, sehingga konsumsi bahan organik mengikuti konsumsi bahan kering. Kamal (1994), menyatakan bahwa konsumsi bahan kering mempunyai korelasi positif terhadap konsumsi bahan organik, karena nutrien yang terkandung dalam bahan organik juga terkandung dalam bahan kering. Putro (2010) menambahkan bahwa jumlah konsumsi bahan kering akan berpengaruh terhadap jumlah konsumsi bahan organik. Banyaknya konsumsi bahan kering akan mempengaruhi besarnya nutrien yang dikonsumsi sehingga jika konsumsi bahan kering tinggi maka akan meningkatkan konsumsi nutrien yang terkandung didalam bahan organik.

Kandungan energi ransum juga merupakan salah satu faktor yang mempengaruhi konsumsi bahan organik. Kandungan TDN ransum P0 64,49\% dan P1 sebesar 65,33\%. Kandungan TDN P1 lebih tinggi dari P0 namun karena peningkatannya tidak terlalu banyak (sedikit) sehingga tidak mempengaruhi konsumsi bahan organik. Hal ini sebagaimana pendapat Kamal (1994) yang menyatakan tinggi rendahnya kandungan energi dalam pakan berpengaruh terhadap konsumsi pakan ternak. Hasil penelitian ini lebih tinggi bila dibandingkan dengan penelitian Astuti et al. (2009) sapi perah yang mendapatkan substitusi 300 $\mathrm{g} /$ hari/liter susu pakan suplemen mempunyai konsumsi bahan organik 10,48 $\mathrm{kg} / \mathrm{ekor} / \mathrm{hari}$ dan suplementasi $300 \mathrm{~g} /$ hari/liter susu pakan suplemen mempunyai konsumsi bahan organik 13,53 $\mathrm{kg} / \mathrm{ekor} / \mathrm{hari}$.

\section{Kecernaan Bahan Kering}

Rerata kecernaan Bahan Kering (KcBK) pada sapi Frieshian Holstein (FH) dalam penelitian ini tercantum pada Tabel 6 .

Rerata kecernaan bahan kering (KcBK) pada masing-masing perlakuan $\mathrm{P} 0$ dan $\mathrm{P} 1$ pada penelitian ini secara berturut-turut adalah 63,67 dan $64,65 \%$. Hasil anova menunjukkan bahwa suplementasi lemak terproteksi tidak mempengaruhi kecernaan bahan kering $(\mathrm{P} \geq 0,05)$. Hal ini karena konsumsi bahan kering maupun konsumsi bahan organik yang relatif sama antara P0 dan P1. Tingkat konsumsi pakan umumnya berpengaruh terhadap kecernaan bahan kering dan bahan organik. Sebagaimana pendapat Tilman et al. (1998) yang menyatakan bahwa salah satu faktor yang mempengaruhi kecernaan adalah jumlah pakan yang dikonsumsi. Hasil penelitian ini lebih tinggi bila dibandingkan sapi perah yang mendapatkan substitusi $300 \mathrm{~g} / \mathrm{hari} /$ liter susu pakan suplemen mempunyai kecernaan bahan kering $61,73 \%$. Namun lebih rendah bila dibandingkan dengan sapi perah yang mendapatkan suplementasi $300 \mathrm{~g} /$ hari/liter susu pakan suplemen mempunyai kecernaan bahan kering sebesar 65,52\% (Astuti et al., 2009).

Hasil ini juga menunjukkan bahwa suplementasi lemak terproteksi tidak memberikan dampak negatif terhadap lingkungan rumen sehingga proses pencernaan fermentatif rumen dapat berjalan dengan baik dibuktikan dengan tren lebih tingginya KcBK P1 daripada P0. Dengan adanya proteksi ini sangat bermanfaat untuk menghindari efek negatif akibat pemberian lemak yang melebihi kebutuhan ternak. Pakan suplemen lemak terproteksi berbentuk tepung pada penelitian ini diharapkan merupakan bentuk lemak terlindung dan merupakan sumber lemak yang efektif dalam bahan pakan ternak ruminansia, karena sistem fermentasi rumen tetap normal, kecernaan asam lemaknya tinggi, dan dapat dengan mudah dicampur dengan beberapa jenis bahan pakan yang lain.

\section{Kecernaan Bahan Organik}

Rerata kecernaan bahan organik pada sapi perah

Tabel 6. Rerata kecernaan bahan kering (KcBK) sapi FH (kg/ekor/hari)

\begin{tabular}{|c|c|c|c|c|c|c|c|}
\hline \multirow{2}{*}{ Perlakuan } & \multicolumn{6}{|c|}{ Ulangan } & \multirow{2}{*}{ Rerata } \\
\hline & 1 & 2 & 3 & 4 & 5 & 6 & \\
\hline P0 & 64,72 & 57,75 & 63,15 & 65,55 & 63,93 & 66,94 & $63,67^{\text {ns }}$ \\
\hline $\mathrm{P} 1$ & 63,28 & 62,95 & 64,13 & 63,38 & 67,97 & 64,65 & $64,65^{\mathrm{ns}}$ \\
\hline
\end{tabular}

NS: non significant (berbeda tidak nyata) 
Tabel 7. Rerata kecernaan bahan organik sapi FH (\%)

\begin{tabular}{|c|c|c|c|c|c|c|c|}
\hline \multirow{2}{*}{ Perlakuan } & \multicolumn{6}{|c|}{ Ulangan } & \multirow{2}{*}{ Rerata } \\
\hline & 1 & 2 & 3 & 4 & 5 & 6 & \\
\hline P0 & 69,60 & 64,05 & 69,22 & 71,26 & 70,03 & 72,24 & $69,40^{\mathrm{ns}}$ \\
\hline $\mathrm{P} 1$ & 69,06 & 68,18 & 70,15 & 68,97 & 72,56 & 68,91 & $69,64^{\mathrm{ns}}$ \\
\hline
\end{tabular}

Frieshian Holstein (FH) dalam penelitian ini tercantum pada Tabel 7.

Rerata kecernaan bahan organik pada masingmasing perlakuan P0 dan P1 pada penelitian ini secara berturut-turut adalah $69,40 \%$ dan $69,64 \%$. Hasil analisis anova menunjukkan bahwa suplementasi lemak terproteksi tidak mempengaruhi kecernaan bahan organik. Hal ini menunjukkan bahwa suplementasi lemak terproteksi 3\% dari ransum belum dapat menaikkan ataupun menurunkan kecernaan bahan organik. Kecernaan bahan organik akan mengikuti kecernaan bahan kering karena di dalam bahan kering terdapat bahan organik. Menurut Tilman et al. (1998) dalam bahan kering terdapat bahan organik dan bahan anorganik, dimana bahan organik terdiri atas karbohidrat, protein dan vitamin sedangkan bahan anorganik terdiri dari mineral sehingga bahan kering sebanding dengan bahan organik. Kamal (1994) menyatakan bahwa pakan terdiri dari air dan bahan kering sedangkan bahan kering terdiri dari bahan organik dan bahan anorganik. Suwandyastuti dan Suparwi (1991) menyatakan bahwa bahan pakan yang mempunyai kandungan nutrien yang sama memungkinkan kecernaan bahan organiknya mengikuti kecernaan bahan keringnya, walaupun terkadang sering juga terjadi perbedaan. Hasil penelitian ini lebih tinggi bila dibandingkan dengan dengan penelitian Ueda et al. (2003) yakni lemak terproteksi berbahan linseed oil dengan kecernaan bahan organik $(\mathrm{KcBO})$ sebesar 43,4\% dan lebih rendah bila dibandingkan dengan penelitian Kowalski (1997), KcBO lemak terproteksi berbahan baku minyak kanola $62,6 \%$ dan KcBO kombinasi minyak kanola dengan bungkil kedelai sebesar $63,7 \%$.

\section{KESIMPULAN}

Pemberian pakan suplemen lemak terproteksi sejumlah $3 \%$ belum memberikan pengaruh terhadap konsumsi dan kecernaan ransum sapi perah Friesian Holstein.

\section{DAFTAR PUSTAKA}

Astuti. A, A. Agus dan S.P.S, Budi. 2009. Pengaruh penggunaan high quality feed supplement terhadap konsumsi dan kecernaan nutrien sapi perah awal laktasi. Buletin Peternakan 33(2): 81-87.

Kamal, M. 1994. Nutrisi Ternak I. Laboratorium Makanan Ternak Fakultas Peternakan Universitas Gadjah Mada. Yogyakarta.
Kowalski, Z.M. 1997. Rumen fermentation, nutrient flow to the duodenum, and digestibility in bulls fed calcium soaps of rapeseed fatty acidsand soya bean meal coated with calcium soaps. Anim. Feed Science Technology 69: 298 - 303.

Pond, W. G., D. C. Church. And K. R. Pond. 1995. Basic Animal Nutrition and Feeding. John Wiley and Sons. New York.

Pramono. A., E. Handayanta., D. T. Widayati., P.P Putro dan Kustono. 2017. Dietary protected feed supplement to increase milk production and quality of dairy cows. Proc. International Conference On Food Science and Engineering. Surakarta.

Pramono. A., Kustono, D.T. Widayati., P.P. Putro., E. Handayanta dan H. Hartadi. 2013. Evaluasi Proteksi Sabun Kalsium Sebagai Pakan Suplemen Berdasarkan Kecernaan Bahan Kering, Bahan Organik dan pH In Vitro di dalam Rumen DanPasca Rumen. Sains Peternakan 11(02): 70-78.

Putro, G.A. 2010. Pengaruh Suplementasi Probiotik Cair EM4 Terhadap Kecernaan Bahan Kering dan Bahan Organik Ransum Domba Lokal Jantan. Skripsi. Fakultas Pertanian Universitas Sebelas Maret. Surakarta.

Santos, J.E.P., T.R. Bilby., W.W. Thatcher., C.R. Staples and F.T. Silvestre. 2008. Long chain fatty acids of diet as factors influencing reproduction in cattle. Reproduction in Domestic Animals 43(2):23-30.

Suwandyastuti, S. N. O dan Suparwi. 1991. Kecernaan Nutrien Rumput Lapang Pada Domba Jantan Fase Tumbuh. Laporan Penelitian. Fakultas Peternakan Universitas Jenderal Soedirman. Purwokerto.

Tillman, A. D., H. Hartadi., S. Reksohadiprodjo., S. Prawiro Kusuma dan S. Lebdosoekoekojo. 1998. Ilmu Makanan Ternak Dasar. Gadjah Mada University Press. Yogyakarta.

Ueda. K., A. Ferlay., J. Chabrot., J.J. Loor., Y. Chilliard and M. Doreau. 2003. Effect of Linseed Oil Supplementation on Ruminal Digestion in Dairy Cows Fed Diets with Different Forage: Concentrate Ratios. Journal of Dairy Science 86:3999-4007.

Utomo, A. J. 2010. Palatabilitas serta Rasio Konsumsi Pakan dan Air Minum kelinci Jantan Lokal Peranakan New Zealand White yang Diberi Pelet atau Silase Ransum Komplit. Skripsi. Fakultas Peternakan Institut Pertanian Bogor. Bogor.

Zachut, M. Dekel., H. Lehrer., A. Arieli., A. Arav., L. Livshitz., S. Yakoby and U. Moallem. 2010. 
Effects of dietary fats differing in n-6: n-3 ratio fed to high-yielding dairy cows on fatty acid composition of ovarian compartments, follicular status, and oocyte quality. Journal of Dairy Science 93:529-545. 